\title{
FIELD SPATIAL AND TEMPORAL PATTERNS OF SOIL WATER CONTENT AND BULK DENSITY CHANGES
}

\author{
Luís Carlos Timm¹; Luiz Fernando Pires²; Renato Roveratti²; Robson Clayton Jacques Arthur²; \\ Klaus Reichardt²*; Júlio Cesar Martins de Oliveira ${ }^{3}$; Osny Oliveira Santos Bacchi² \\ ${ }^{1}$ UFPel/FAEM - Depto de Engenharia Rural, C.P. 354 - 96001-970 - Pelotas, RS - Brasil. \\ ${ }^{2}$ USP/CENA - Lab. de Física de Solo, C.P. 96 - 13416-000 - Piracicaba, SP - Brasil. \\ ${ }^{3}$ EEP - Depto. de Física, Av. Monsenhor Martinho Salgot, 560 - 13414-040 - Piracicaba, SP - Brasil. \\ *Corresponding author <klaus@cena.usp.br>
}

\begin{abstract}
Soil water content $(\theta)$ and bulk density $\left(\rho_{s}\right)$ greatly influence important soil and plant processes, such as water movement, soil compaction, soil aeration, and plant root system development. Spatial and temporal variability of $\theta$ and $\rho_{\mathrm{s}}$ during different periods of the year and different phases of crops are of fundamental interest. This work involves the characterization of spatial and temporal patterns of $\theta$ and $\rho_{\mathrm{s}}$ during different climatic periods of year, aiming to verify whether there are significant temporal changes in $\rho_{\mathrm{s}}$ at the soil surface layer when submitted to wetting and drying cycles. The field experiment was carried out in a coffee plantation, Rhodic Kandiudalf soil, clayey texture. Using a neutron/gamma surface probe, $\theta$ and $\rho_{\mathrm{s}}$ were measured meter by meter along a $200 \mathrm{~m}$ spatial transect, along an interrow contour line. During the wet period there was no difference of spatial patterns of $\theta$ while during the dry period differences were observed, and can be associated to precipitation events. It was also observed that there are $\rho_{\mathrm{s}}$ temporal changes at the soil surface along the studied period as a consequence of the in situ wetting and drying cycles. Key words: neutron/gamma surface probe, wetting/drying cycles, spatial and temporal variability
\end{abstract}

\section{PADRÕES ESPACIAL E TEMPORAL DE MUDANÇAS DA UMIDADE E DENSIDADE DO SOLO NO CAMPO}

\begin{abstract}
RESUMO: Umidade $(\theta)$ e densidade do solo $\left(\rho_{\mathrm{s}}\right)$ influenciam importantes processos no solo e planta tais como: movimento de água, compactação do solo, aeração do solo e desenvolvimento radicular. Baseado neste fato, questões referentes à variabilidade espacial e temporal de $\theta$ e $\rho_{\mathrm{s}}$ para diferentes períodos do ano e diferentes fases de desenvolvimento da cultura do café tornam-se de extremo interesse. Este trabalho teve como objetivo caracterizar padrões espaciais e temporais de $\theta$ e $\rho_{\mathrm{s}}$ durante diferentes períodos do ano e verificar se existem mudanças temporais significativas de $\rho_{\mathrm{s}}$ na superfície do solo quando submetida a ciclos de umedecimento/secagem. O experimento foi conduzido em campo cultivado com café em um solo classificado como Nitossolo Vermelho Eutrófico. O experimento iniciou-se em maio de 2001 com espaçamento de $1,75 \mathrm{~m}$ entre linhas e $0,75 \mathrm{~m}$ entre plantas. Medidas de $\theta$ e $\rho_{\mathrm{s}}$ foram feitas metro a metro ao longo de 200 $\mathrm{m}$ usando uma sonda de superfície nêutron/gama. Durante o período úmido não houve padrões de diferença espacial para $\theta$, enquanto que para o período seco o contrário foi observado. Estes padrões podem ser associados a eventos de precipitação alterando a estrutura de correlação espacial para observações adjacentes de $\theta$. Para $\rho_{\mathrm{s}}$ existem mudanças temporais na superfície do solo ao longo do período estudado como uma conseqüência dos ciclos de umedecimento/secagem no campo.

Palavras-chave: sonda de superfície nêutron/gama, ciclos de umedecimento/secagem, variabilidade espacial e temporal
\end{abstract}

\section{INTRODUCTION}

Several factors affect crop productivity, especially the edaphic, climatic and management factors. Among edaphic factors, physico-chemical attributes of farmed soils stand out because they affect directly plants dry matter accumulation in different periods of the year and in all development phases of the crop. Tominaga et al. (2002) showed that on tropical soils, physical attributes such as soil water content and bulk density, greatly influence important soil and plant processes like water movement (Reichardt \& Timm, 2004), soil compaction (Logsdon \& Karlen, 2004), soil aeration (Stepniewski et al., 1994), and plant root system development (Boone \& Veen, 1994).

An important question is whether soil bulk density can be considered a static soil property or if small temporal changes are important (Logsdon \& Karlen, 2004). In this sense, Logsdon \& Cambardella (2000) detected significant temporal changes in near- 
surface soil bulk densities for tillage systems in a subhumid climate.

At soil surface, soil water content influences the partitioning of precipitation into infiltration and runoff, and controls evapotranspiration by controlling evaporation and water availability to plants, therefore affecting also the partitioning of latent and sensible heat (Grayson et al., 1997). An improved understanding of the spatial distribution of soil water content is thus useful for a range of hydrologic factors affecting crop production. However, an important question for hydrology is "how does the temporal variation in soil water content affect its spatial patterns evaluated through geostatistical tools”. Ahuja et al. (1993) reported that temporal changes of soil surface moisture two days after wetting revealed a lot about the spatial distribution of drainage and hydraulic properties within the soil profile.

Wendroth et al. (1999) monitored the soil water pressure heads in surface horizons at two field sites, a sandy loam and a heavy clay soil, between April and November 1995 in north-east Germany, and concluded that with decreasing soil water pressure head, the variance of $\log _{10}(-h)$ decreased to a critical value, for which a spatial correlation structure disappeared. On the other hand, with further drying, its variance increased again, and a spatial range of correlation appeared.

Soil spatial variability occurs at different scales and is related to variations of the parent material, climate, relief, organisms and time, i.e., related to the processes of soil formation and/or effects of adopted management practices for each agricultural use (McGraw, 1994). Large areas have been managed as homogeneous, although presenting a considerable spatial variability inherent to the soil, causing the appearance of zones of distinct soil physical properties and distinct soil fertility (Wendroth et al., 2003).

Several statistical tools have been used to evaluate the variabilities of soil attributes, which can contribute to improve management and the understanding of atmosphere-plant-soil interactions (Vieira et al., 1981; Cassel, 1983; Morkoc et al., 1985; Wendroth et al., 2001; 2003; Dourado-Neto et al., 1999; Timm et al., 2003; 2004; Tominaga et al., 2002; Martínez \& Zinck, 2004). This work studies the importance of soil water content and bulk density changes, using some of these tools to characterize spatial and temporal patterns of changes during different climatic periods of the year, with the objective of examining possible differences that might occur when a soil is submitted to wetting or drying processes.

\section{MATERIAL AND METHODS}

The field experiment was carried out along interrows of a coffee plantation in Piracicaba, SP, Bra-

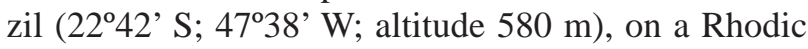
Kandiudalf, clayey texture. According to Köppen's classification, the region's climate is the Cwa type, tropical highland, mesothermal with dry winter. Average values for air temperature, rainfall, and relative humidity are $21.2^{\circ} \mathrm{C} ; 1,253 \mathrm{~mm} /$ year; and $74 \%$, respectively. The dry season covers June-August, July being the driest month. During spring-summer, October to March, very high intensity rainfall events are common, several of them reaching $50 \mathrm{~mm} \mathrm{~h}^{-1}$ or more. Soil water content $\theta\left(\mathrm{m}^{3} \mathrm{~m}^{-3}\right)$ and soil bulk density $\rho_{\mathrm{s}}\left(\mathrm{Mg} \mathrm{m}^{-3}\right)$ were evalueted in a coffee crop field (variety Catuai Red IAC44) planted in May 2001, along rows $1.75 \mathrm{~m}$ apart, with $0.75 \mathrm{~m}$ between plants. This narrow spacing between coffee plants $(0.75 \mathrm{~m})$ resulted in high density plant ranks. During the development of the crop, according to Rena \& Maestri (1987), the ranked plants undergo less water stress due to their adaptation to a higher intra-specific competition, i.e., plant roots grow deeper into the soil seeking water and nutrients. The ranked plant system also reduces leaf and soil temperatures. Mendes (2001) noted that although the progenies of the Catuai variety are vigorous, they should not be submitted to stress conditions such as high periods of hydric deficiency, among others.

Monitoring of $\theta$ and $\rho_{\mathrm{s}}$ at the soil surface layer $(0-0.15 \mathrm{~m})$ was made along the bare interrow, when the coffee crop was two years old (April to August 2003), during the end of its vegetative cycle (Marin, 2003). At the first $\theta$ and $\rho_{\mathrm{s}}$ evaluation (April 2003) coffee plants were all green along the spatial transect, presenting large quantity of leaves, being about $1 \mathrm{~m}$ tall, shading a $1 \mathrm{~m}$ strip of interrow, leaving a bare central strip of about $0.75 \mathrm{~m}$ on which measurements were taken, in a period without hydric stress problems. During the July to August 2003 period, hydric stress problems could visually be observed on the plants, causing leaf loss and a consequent higher exposition of the soil surface to solar radiation. This period corresponds to the winter season in the Southern Hemisphere, in which events of precipitation are rare and of low intensity in Piracicaba.

This study focuses $\theta$ and $\rho_{\mathrm{s}}$ measurements carried out every meter along a 200 meter spatial transect. Measurements were made using a neutron-gamma surface gauge (SG), which yields average values of the 0-0.15 m soil layer, calibrated for this particular soil according to Cássaro et al. (2000). The advantage of this methodology is that the "sampled" layer remains undisturbed for several measurements made at the very 
same point. Two distinct climatic periods were chosen: i. April to May 2003, a wet period - $1^{\text {st }}$ measurement $M_{1}$ : 04/24/2003; $2^{\text {nd }}$ measurement $\mathrm{MW}_{2}$ : 05/07/2003; $3^{\text {rd }}$ measurement $\mathrm{MW}_{3}: 05 / 23 / 2003$; and ii. July to $\mathrm{Au}-$ gust 2003, a dry period - $1^{\text {st }}$ measurement $\mathrm{MD}_{1}:$ 07/04/ 2003; $2^{\text {nd }}$ measurement $\mathrm{MD}_{2}: 07 / 18 / 2003$; $3^{\text {rd }}$ measurement $\mathrm{MD}_{3}$ : 08/02/2003. These 6 dates (measurements) were chosen according to the possibility of obtaining a good contrast between wetting and drying processes. In any other season of the year this would not be possible.

Daily variation of precipitation and reference evapotranspiration ETo of the experimental field are presented for the period under study in Figure 1. MW was measured five days after a precipitation event of $12.2 \mathrm{~mm}(04 / 19 / 2003) ; \mathrm{MW}_{2}$ after two precipitation events of $26.1 \mathrm{~mm}$ and $9.4 \mathrm{~mm}$ on days 05/02 and 05/
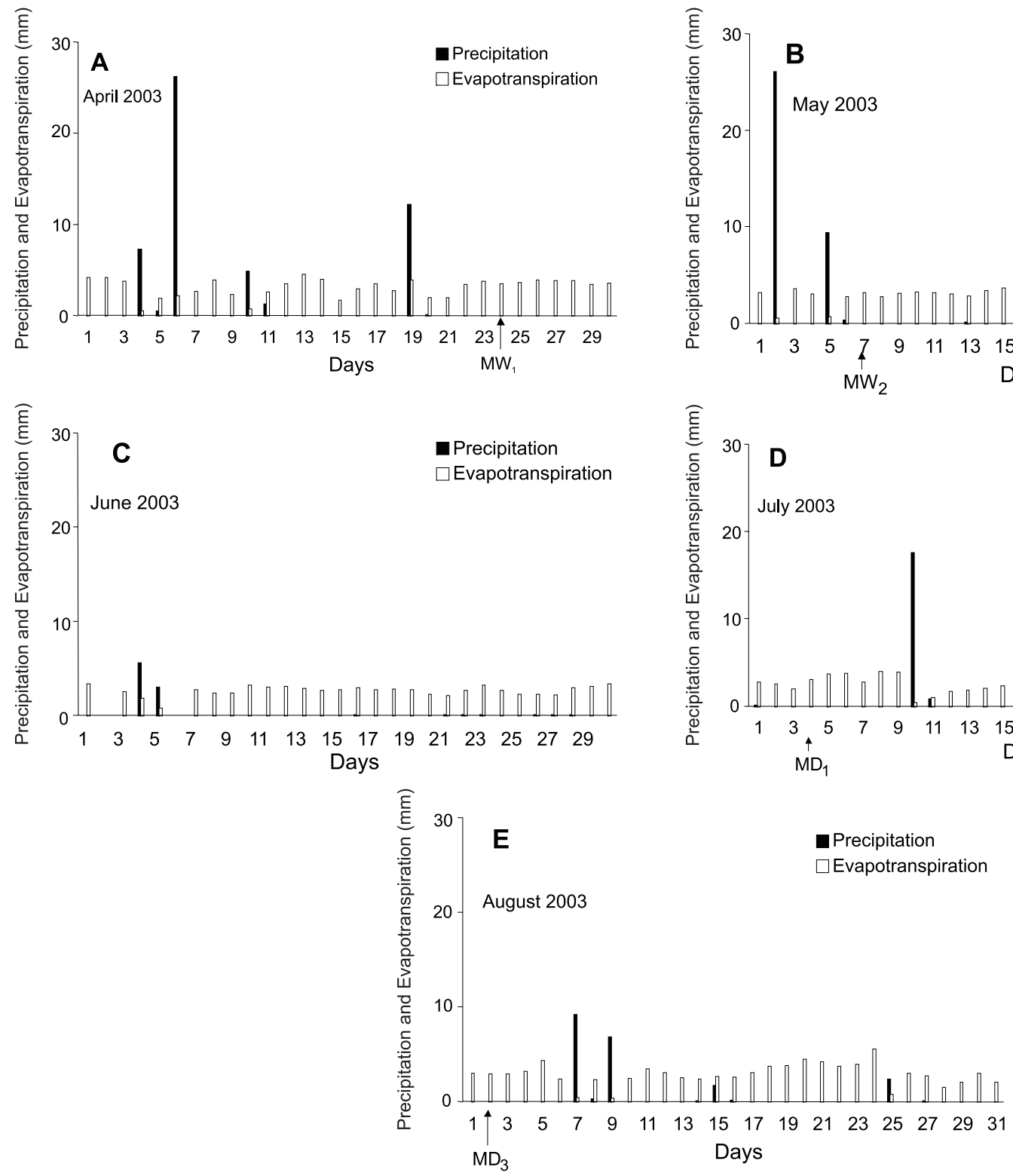
sons. tigated.

05/2003, shown on Figure 1. The third spatial series $\mathrm{MW}_{3}$ was measured after a period of sixteen days without precipitation events, the crop being submitted to a long period of evapotranspiration only. Changes in $\theta$ between consecutive measurements $(\Delta \theta)$ were analysed to examine wetting and drying cycles during both sea-

Soil texture (clay, sand and silt contents) was evaluated using disturbed soil samples, collected at the end of the experiment, also every meter along the 200 meter spatial transect, in the $0-0.15 \mathrm{~m}$ soil layer at the same points where $\theta$ and $\rho_{\mathrm{s}}$ were taken. Details about the soil mechanical analysis can be found in EMBRAPA (1997). Relations of soil texture variability to water content and bulk density were also inves-
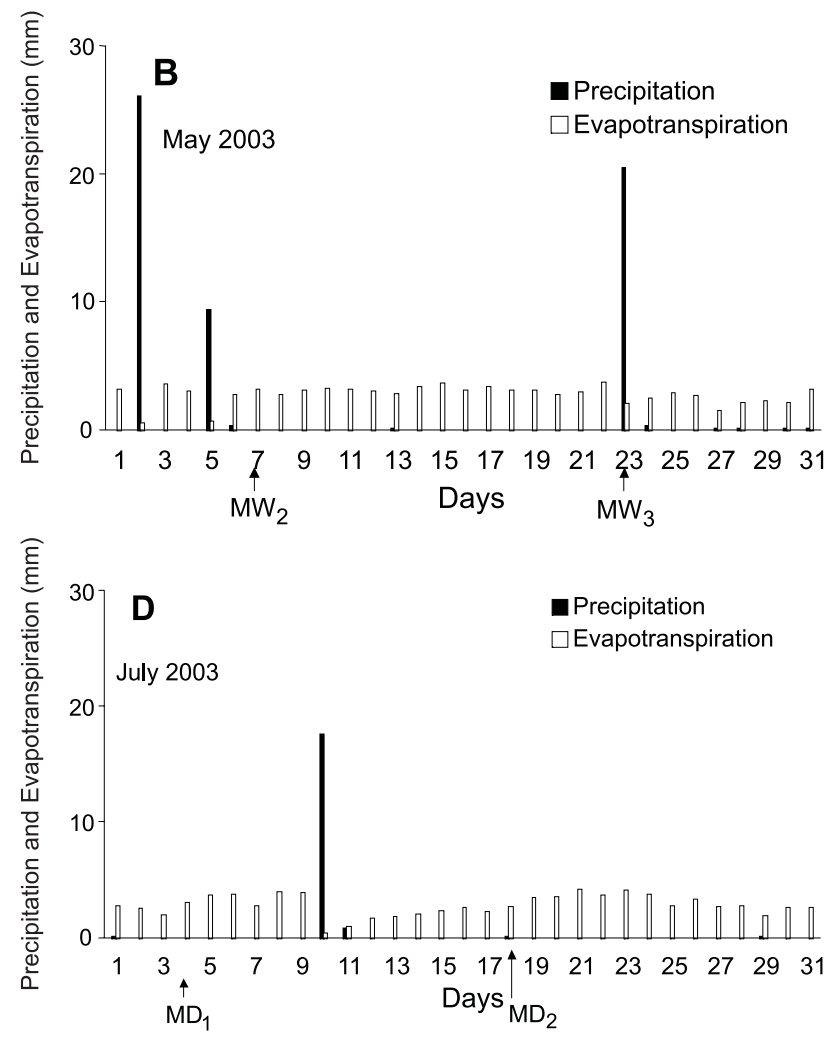
Statistical analysis was performed using the classical concepts of mean, standard deviation, coefficients of variation and the t test $(\alpha=0.05)$ through the GLM procedure of SAS $^{\circledR}$ (SAS Institute, 1996). The significance level used for the variance analysis was of $5 \%$ through the Duncan test, using the LSMEANS procedure. To analyse and characterize spatial data distributions, geostatistical tools such as autho- and cross-correlations (Nielsen \& Wendroth, 2003) were used:

$$
\begin{aligned}
& C(j)=\frac{1}{(n-1-j)}\left[\sum_{i=1}^{n-j}\left(x_{i}-\bar{x}\right)\left(x_{i+j}-\bar{x}\right)\right] \\
& r(j)=\frac{C(j)}{s^{2}} \\
& r_{c}(j)=C\left(x_{i}, y_{i+j}\right)\left(\sqrt{s_{x}^{2} \cdot s_{y}^{2}}\right)^{-1}
\end{aligned}
$$

where $n$ is the number of observations; $j$ is the number of lags $h$ between observations used for correlation; $\mathrm{x}_{\mathrm{i}}$ the variable at position $\mathrm{i}$ and $\mathrm{x}_{\mathrm{i}+\mathrm{j}}$ at position $\mathrm{i}+\mathrm{j}$; $r(\mathrm{j})$ are correlation coefficients for $\mathrm{j}$ lags; $\mathrm{s}^{2}$ the variance; and the cross-correlations $r_{c}(j): x_{i}$ and $\mathrm{y}_{\mathrm{i}+\mathrm{j}}$ are the variables under study, with variances $s_{x}^{2}$ and $s_{y}^{2}$.

To determine whether precipitation events change the spatial correlation structure among the adjacent $\theta$ observations, autocorrelograms of each spatial series were calculated, since according to Nielsen \& Wendroth (2003) the autocorrelation function ACF is a primary diagnostic tool which indicates if there is a spatial or temporal pattern of on-site sampled data. The number of points considered as replicates for calculating the $\rho_{\mathrm{s}}$ mean values for each data set was also calculated. After this, the Duncan statistical test ( $\alpha=0.05)$ was used to compare the mean values of each data set using SAS software (SAS Institute, 1996).

\section{RESULTS AND DISCUSSION}

\section{Wet period $\mathrm{MW}_{1}, \mathrm{MW}_{2}, \mathrm{MW}_{3}$ (April 24 to May 23, 2003): precipitation $56.4 \mathrm{~mm}$}

To visualize the spatial distribution of the soil water content data sets, Figure 2 is presented as a sample, corresponding to: $\mathrm{MW}_{1}$ 04/24/2003. The statistical parameters for all six dates are shown in Table 1.

For the MW series, $\theta_{\text {ave }}$ is inversely related to the CV showing a clear tendency of increased variability with soil drying, i.e., the dispersion of soil water contents around their mean is lower when the soil is wet. The $\mathrm{MW}_{2}$ measurement had the highest $\theta_{\text {ave }}$ because of recent precipitation, whereas the $\mathrm{MW}_{3}$ had the lowest $\theta_{\text {ave }}$ because of the previous dry period. The wetting spatial patterns of $\Delta \theta$ presented higher dispersion of data in relation to its mean $(\mathrm{CV}=32.3 \%)$ as compared to the drying spatial pattern $(\mathrm{CV}=22.1 \%)$. This fact may be explained by the hysteresis effect, which can strongly affect the water redistribution in the soil profile (Kutilek \& Nielsen, 1994). Figure 3 presents the spatial dependence of $\theta$ data sets in relation to their neighborhood for the three different dates.

Adjacent $\theta$ observations for $\mathrm{MW}_{1}$ are spatially dependent up to $2 \mathrm{~m}$ (2 lags), i.e., based on the t test

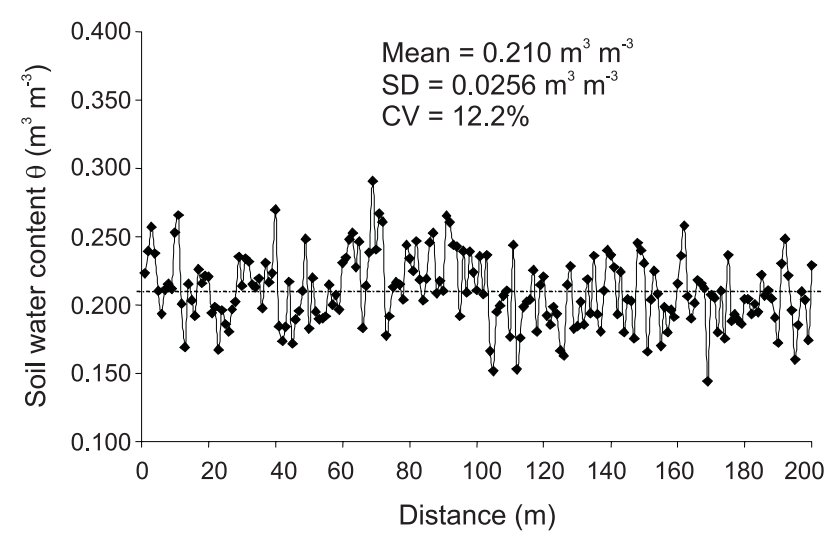

Figure 2 - Soil water content $\theta\left(\mathrm{m}^{3} \mathrm{~m}^{-3}\right)$ distribution along transect for date $\mathrm{MW}_{1}(04 / 24 / 2003)$.

Table 1 - Classical statistics parameters for $\mathrm{MW}_{1}, \mathrm{MW}_{2}, \mathrm{MW}_{3}, \mathrm{MD}_{1}, \mathrm{MD}_{2}$ and $\mathrm{MD}_{3}$ soil water content $\theta\left(\mathrm{m}^{3} \mathrm{~m}^{-3}\right)$ data sets: average $\left(\theta_{\text {ave }}\right)$; stand deviation $[\mathrm{s}(\theta)]$; maximum value $\left(\theta_{\max }\right)$; minimum value $\left(\theta_{\min }\right)$; amplitude between $\theta_{\max }$ and $\theta_{\min }$; coefficient of variation (CV).

\begin{tabular}{lcccccc}
\hline & $\theta_{\text {ave }}$ & $\mathrm{s}(\theta)$ & $\theta_{\max }$ & $\theta_{\min }$ & Amplitude & \multicolumn{1}{c}{ CV\% } \\
\hline $\mathrm{MW}_{1}$ & 0.210 & 0.025 & 0.291 & 0.144 & 0.147 & 12.2 \\
$\mathrm{MW}_{2}$ & 0.304 & 0.025 & 0.369 & 0.233 & 0.136 & 8.3 \\
$\mathrm{MW}_{3}$ & 0.134 & 0.021 & 0.196 & 0.078 & 0.118 & 15.7 \\
$\mathrm{MD}_{1}$ & 0.163 & 0.025 & 0.219 & 0.095 & 0.124 & 15.2 \\
$\mathrm{MD}_{2}$ & 0.194 & 0.025 & 0.248 & 0.133 & 0.115 & 12.7 \\
$\mathrm{MD}_{3}$ & 0.147 & 0.022 & 0.207 & 0.098 & 0.108 & 14.9 \\
\hline
\end{tabular}


$(\alpha=0.05$ ), observations separated by a distance of less than $2 \mathrm{~m}$ would not have different soil water content. It is important to note that $1 \mathrm{lag}=1 \mathrm{~m}$ so that the number of lags becomes equal to distances. For $\mathrm{MW}_{2}$ in which the highest $\theta$ values were measured at any location is representative for a nearly $10 \mathrm{~m}$ domain, i.e., adjacent $\theta$ observations are spatially dependent up to $5 \mathrm{~m}$ using the t test $(\alpha=0.05)$. Adjacent $\theta$ observations on $\mathrm{MW}_{3}$ are spatially dependent up to $4 \mathrm{~m}$ using the same statistical test. It was not possible to identify for the wet period, a relationship between the precipitation event and spatial pattern of $\theta$ along the transect, since the spatial correlation structure presented in Figures 3B $\left(\mathrm{MW}_{2}\right)$ and $3 \mathrm{C}\left(\mathrm{MW}_{3}\right)$ were similar. Grayson et al. (1997) proposed two hypotheses in respect to surface $\theta$ spatial patterns in temperate regions of Austra-
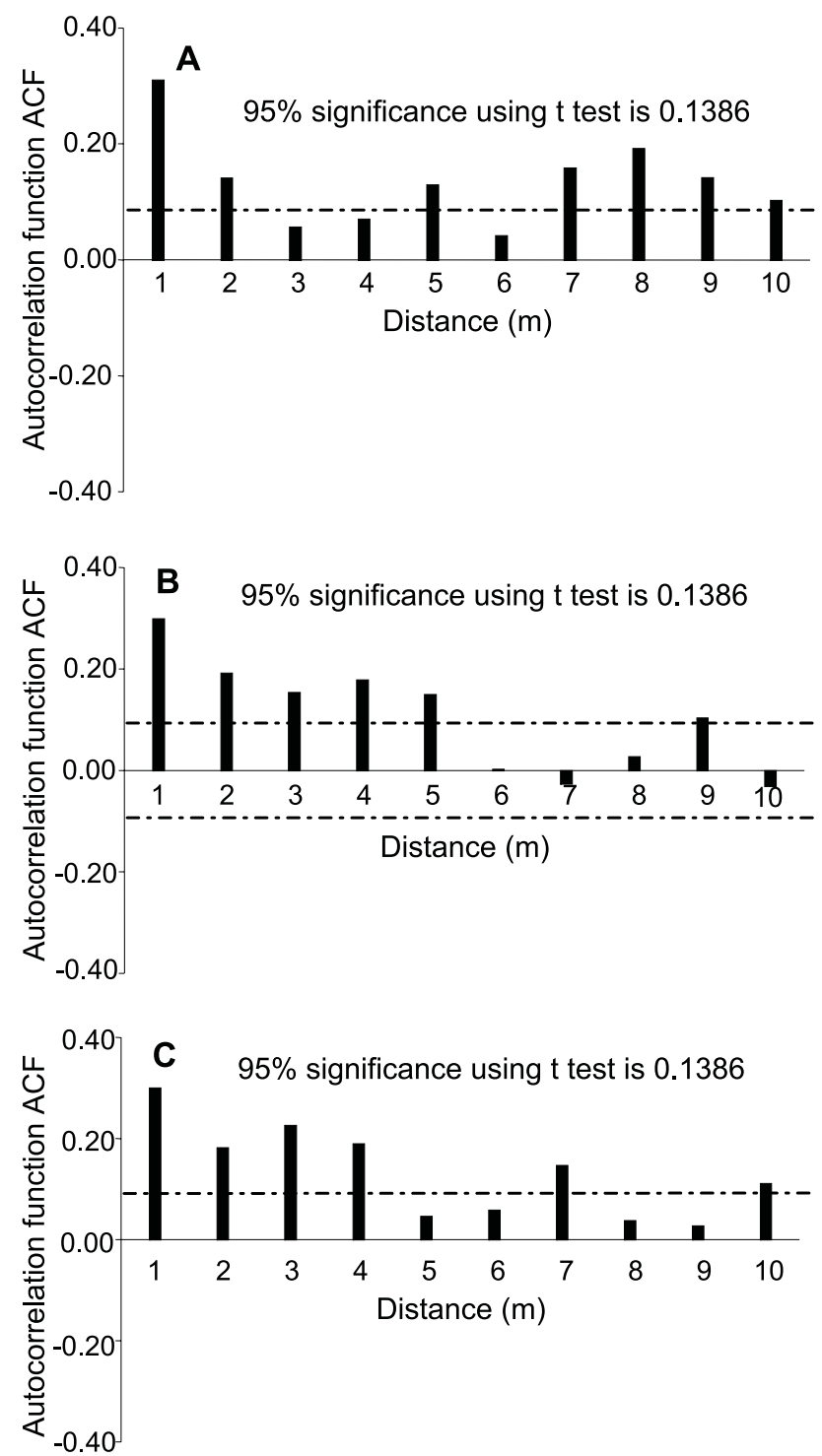

Figure 3 - Autocorrelation functions (ACF) for soil and water content data sets for dates of: (A) $\mathrm{MW}_{1}(04 / 24 / 2003)$; (B) $\mathrm{MW}_{2}$ (05/07/2003); and (C) $\mathrm{MW}_{3}(05 / 23 / 2003)$. lia (and similar climates elsewhere): i. in periods when precipitation continually exceeds evapotranspiration, it would be expected that the soil water content data set would present a spatial correlation structure; and ii. in periods when evapotranspiration continually exceeds precipitation, it would be expected that the soil water content data set would present a more random appearance, i.e., a data set without a spatial correlation structure among observations. These hypotheses were formulated for temperate regions, different of the tropical highland climate of the Piracicaba region, which has higher rainfall and a clayey loam soil. From all soil bulk density $\left(\rho_{\mathrm{s}}\right)$ data sets $\left(\mathrm{MW}_{1}, \mathrm{MW}_{2}\right.$ and $\left.\mathrm{MW}_{3}\right)$ a sample $\left(\mathrm{MW}_{1}\right)$ is presented in Figure 4. Table 2 shows all classical statistics parameters for these data sets.

The CV ranged from $3.8\left(\mathrm{MW}_{2}\right)$ to $4.5 \%$ $\left(\mathrm{MW}_{3}\right)$, lower than in the case of $\theta$, an indication that observations of $\rho_{\mathrm{s}}$ present a certain spatial homogeneity along the spatial transect for the three different dates. For the date at which the highest $\theta$ values were observed $\left(\mathrm{MW}_{2}\right)$ it was registered that $\rho_{\mathrm{s}}$ presented the lowest dispersion in relation to their mean $(\mathrm{CV}=$ $3.8 \%)$, i.e., CVs for $\theta$ and $\rho_{\mathrm{s}}$ data sets are lower when the soil is wet, indicating higher spatial homogeneity of data in this condition. The autocorrelation function ACF for the $\rho_{\mathrm{s}}$ data sets are shown in Figure 5.

Adjacent $\rho_{\mathrm{s}}$ observations are spatially correlated only up to $1 \mathrm{~m}$ for $\mathrm{MW}_{1}$ (Figure $5 \mathrm{~A}$ ) and $\mathrm{MW}_{2}$ (Figure 5B), with no spatial correlation for $\mathrm{MW}_{3}$ (Figure 5C), presenting a random behavior at this date. Crosscorrelation functions CCF for the differences $\Delta \theta$ and $\Delta \rho_{\mathrm{s}}$ for both wet periods, are shown in Figure 6.

For the wet soil (MW $\mathrm{MW}_{1}$ to $\mathrm{MW}_{2}$, Figure 6A) as well as for the dry soil ( $\mathrm{MW}_{2}$ to $\mathrm{MW}_{3}$, Figure 6B) there is only a significant spatial correlation between $\theta$ and $\rho_{\mathrm{s}}$ variations at the same spatial point of transect (lag $=0$ ), showing that they are not spatially correlated, following a random distribution. The spatial distribution of clay, sand and silt contents of the 0-0.15 m layer

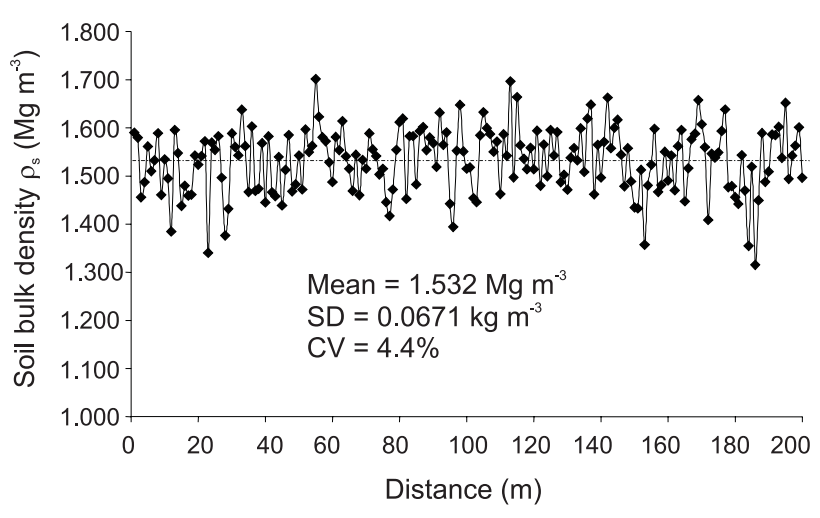

Figure 4 - Soil bulk density $\rho_{\mathrm{s}}\left(\mathrm{Mg} \mathrm{m}^{-3}\right)$ distribution along the transect for $\mathrm{MW}_{1}(04 / 24 / 2003)$. 
Table 2 - Classical statistics parameters for $\mathrm{MW}_{1}, \mathrm{MW}_{2}, \mathrm{MW}_{3}, \mathrm{MD}_{1}, \mathrm{MD}_{2}$ and $\mathrm{MD}_{3}$ soil bulk density $\rho_{\mathrm{s}}\left(\mathrm{Mg} \mathrm{m}^{-3}\right)$ data sets: average $\left(\rho_{\text {ave }}\right)$; stand derivation $[s(\rho)]$; maximum value $\left(\rho_{\max }\right)$; minimum value $\left(\rho_{\min }\right)$; amplitude between $\rho_{\max }$ and $\rho_{\min }$; coefficient variation $(\mathrm{CV})$.

\begin{tabular}{lllllcc}
\hline & $\rho_{\mathrm{s} \text { (ave) }}$ & $\mathrm{s}\left(\rho_{\mathrm{s}}\right)$ & $\rho_{\mathrm{s}(\max )}$ & $\rho_{\mathrm{s}(\min )}$ & Amplitude & $\mathrm{CV} \%$ \\
\hline $\mathrm{MW}_{1}$ & 1.532 & 0.067 & 1.702 & 1.315 & 0.387 & 4.4 \\
$\mathrm{MW}_{2}$ & 1.520 & 0.058 & 1.663 & 1.320 & 0.343 & 3.8 \\
$\mathrm{MW}_{3}$ & 1.495 & 0.067 & 1.678 & 1.304 & 0.374 & 4.5 \\
$\mathrm{MD}_{1}$ & 1.552 & 0.076 & 1.734 & 1.298 & 0.436 & 4.9 \\
$\mathrm{MD}_{2}$ & 1.558 & 0.072 & 1.733 & 1.260 & 0.473 & 4.6 \\
$\mathrm{MD}_{3}$ & 1.579 & 0.067 & 1.709 & 1.348 & 0.361 & 4.2 \\
\hline
\end{tabular}
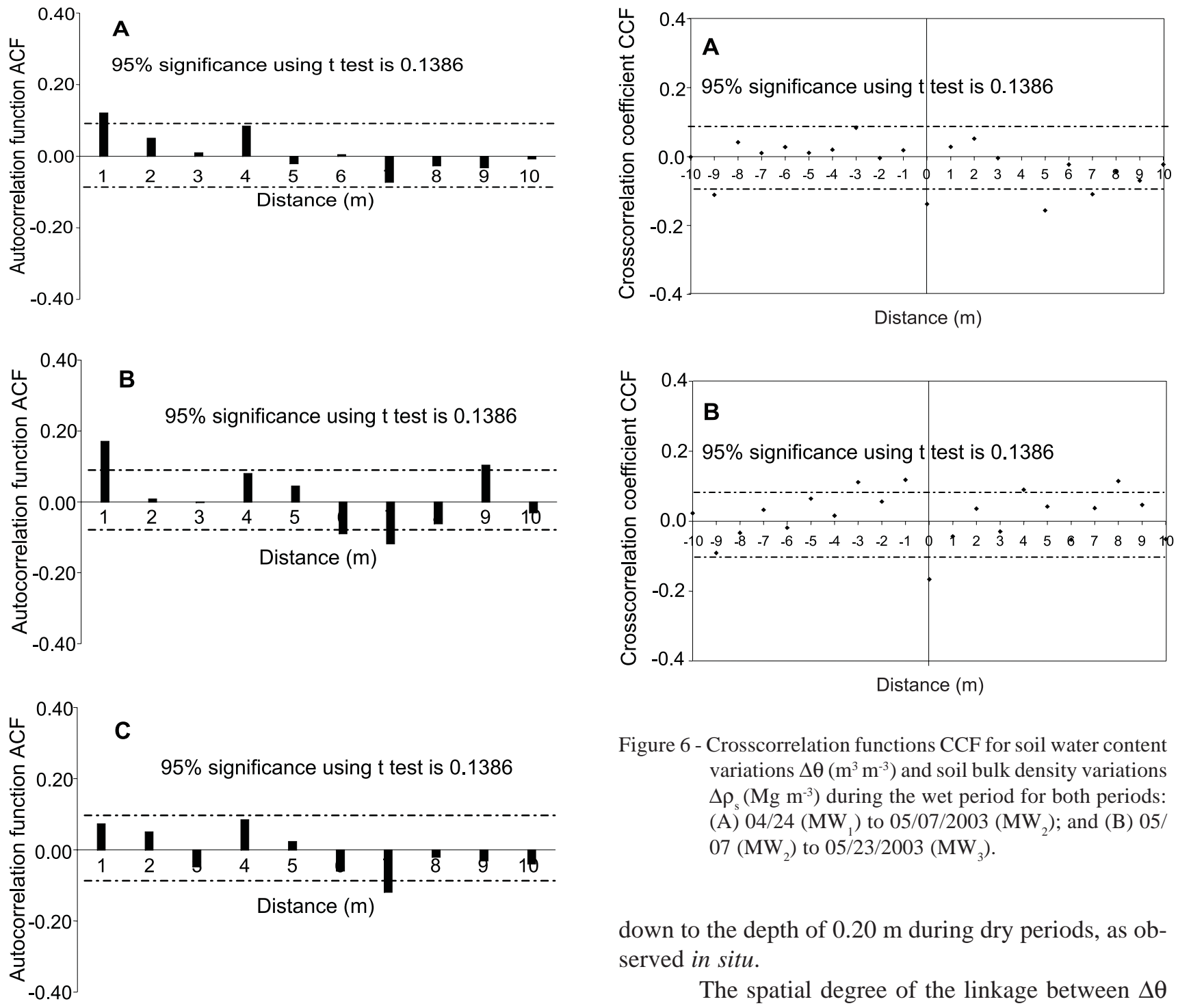

Figure 6 - Crosscorrelation functions CCF for soil water content variations $\Delta \theta\left(\mathrm{m}^{3} \mathrm{~m}^{-3}\right)$ and soil bulk density variations $\Delta \rho_{\mathrm{s}}\left(\mathrm{Mg} \mathrm{m}^{-3}\right)$ during the wet period for both periods: (A) $04 / 24\left(\mathrm{MW}_{1}\right)$ to $05 / 07 / 2003\left(\mathrm{MW}_{2}\right)$; and (B) 05/ $07\left(\mathrm{MW}_{2}\right)$ to $05 / 23 / 2003\left(\mathrm{MW}_{3}\right)$.

down to the depth of $0.20 \mathrm{~m}$ during dry periods, as observed in situ.

The spatial degree of the linkage between $\Delta \theta$

Figure 5 - Autocorrelation functions ACF for soil bulk density $\left(\rho_{\mathrm{S}}\right)$ sets for dates: (A) $\mathrm{MW}_{1}(04 / 24 / 2003) ;(\mathrm{B}) \mathrm{MW}_{2}$ (05/07/2003); and (C) $\mathrm{MW}_{3}(05 / 23 / 2003)$.

along the transect can be observed in Figure 7. The soil, as mentioned before, is clayey with predominance of 1:1 clay minerals (mainly kaolinite) with visible swelling and shrinking movements causing cracks and soil texture for both wet periods was also made through crosscorrelograms (Figure 8). A significant correlation was found at the same spatial point between $\Delta \theta$ in the $M W_{1}$ to $M W_{2}$ period and silt content (Figure $8 \mathrm{~A}$ ), and no significant correlation with clay or sand. From Figures $8 \mathrm{~B}$ and $\mathrm{C}$, a significant correlation was found at the same spatial point between $\Delta \theta$ and clay content as well as silt content in the next $\mathrm{MW}_{2}$ 


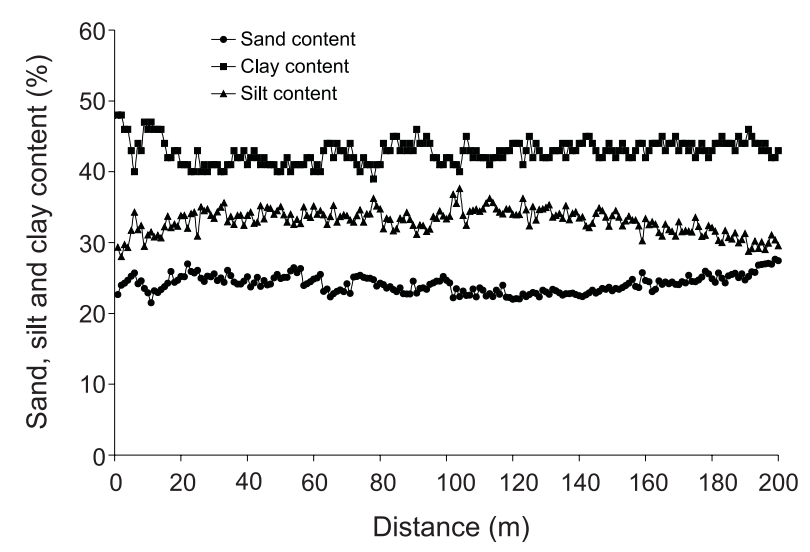

Figure 7 - Clay, sand and silt content distributions, meter by meter, along the $200 \mathrm{~m}$ spatial transect.
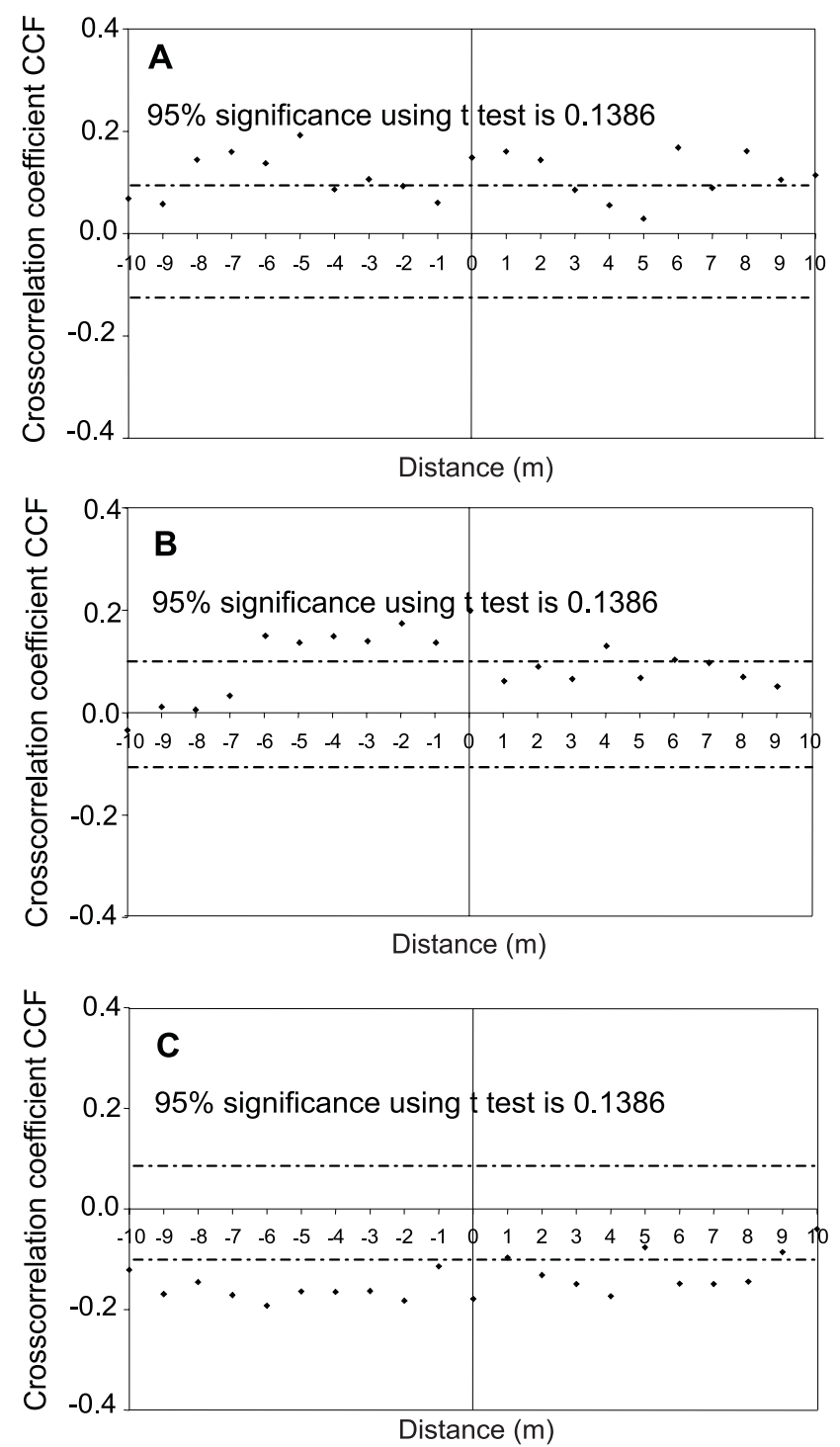

Figure 8 - Crosscorrelation functions CCF for soil water content variations $\Delta \theta\left(\mathrm{m}^{3} \mathrm{~m}^{-3}\right)$ for the wet period: (A) $\Delta \theta$ (MW (04/24) to $\left.\mathrm{MW}_{2}(05 / 07 / 2003)\right)$ and silt content; (B) $\Delta \theta\left[\mathrm{MW}_{2}(05 / 07)\right.$ to $\left.\mathrm{MW}_{3}(05 / 23 / 2003)\right]$ and clay content; and (C) $\Delta \theta\left[\mathrm{MW}_{2}(05 / 07)\right.$ to $\mathrm{MW}_{3}(05 / 23 /$ 2003)] and silt content. to $\mathrm{MW}_{3}$ period, indicating that during the drying of the soil, $\Delta \theta$ at the same point is correlated with the $\Delta \rho_{\text {s }}$ (soil structure) and with clay and silt contents which are the soil particles of lowest diameter and more important for soil water retention when the soil is drying. Nielsen \& Wendroth (2003) comment that near soil water saturation, retention of water is not dominated by the total soil particle surface area, but is influenced more by soil aggregation and the internal architecture of soil pores (soil structure).

Dry period $\mathrm{MD}_{1}, \mathrm{MD}_{2}, \mathrm{MD}_{3}$ (July 04 to August 02, 2003): $18.6 \mathrm{~mm}$

The classical statistics parameters for these data sets are also presented in Table $1 . \mathrm{MD}_{3}$ presented mean of $0.147 \mathrm{~m}^{3} \mathrm{~m}^{-3}$ which corresponds to the lowest $\theta_{\text {ave }}$ measured along the spatial transect in all periods. $\mathrm{MD}_{2}$ period was taken six days after two precipitation events and this is the reason why we observed the highest $\theta_{\text {ave }}$ of the dry period at this date. After 16 days without precipitation, when the highest evapotranspiration was observed, measurements of $\mathrm{MD}_{3}$ were taken with the lowest $\theta$ observations along the transect.

The wetting spatial pattern of the differences $\Delta \theta$ presented a higher dispersion in relation to its mean (CV of 91.4\%) as compared to the drying spatial pattern (CV of 60.3\%), the same behavior as in the wet period. Figure 9 presents the autocorrelograms of these data sets.

The spatial dependency of $\theta$ up to one lag for $\mathrm{MD}_{1}$ (Figure 9A) means that q measured at any location represents the soil water content of a $2 \mathrm{~m}$ domain, observations being spatially independent among them beyond this. For $\mathrm{MD}_{2}$ (Figure 9B), which includes the highest $\theta$ values in this period, adjacent $\theta$ observations are spatially dependent up to eight lags $(9 \mathrm{~m})$, and for $\mathrm{MD}_{3}$ (Figure 9C), up to $2 \mathrm{~m}$. A joint analysis indicates that the precipitation event (07/10/2003) modified the spatial correlation structure of soil water content data sets for the dry period, i.e., the spatial correlation range for the soil water content data set measured at date of $\mathrm{MD}_{2}$ (Figure 9B) was higher in comparison to the other two dates. This fact can be associated to the presence of cracks along the spatial transect due to wetting and drying cycles, causing a soil mass contraction and increasing $\rho_{\mathrm{s}}$ of the soil matrix between cracks. This increase in $\rho_{\mathrm{s}}$ reduces vertical water infiltration and facilitates lateral water movement (cracks form preferential channels), increasing the similarity between adjacent $\theta$ observations.

Simultaneously measured $\rho_{\mathrm{s}}$ data sets (Table 2 ), show again that the observations present a certain spatial homogeneity along the transect for the three dif- 

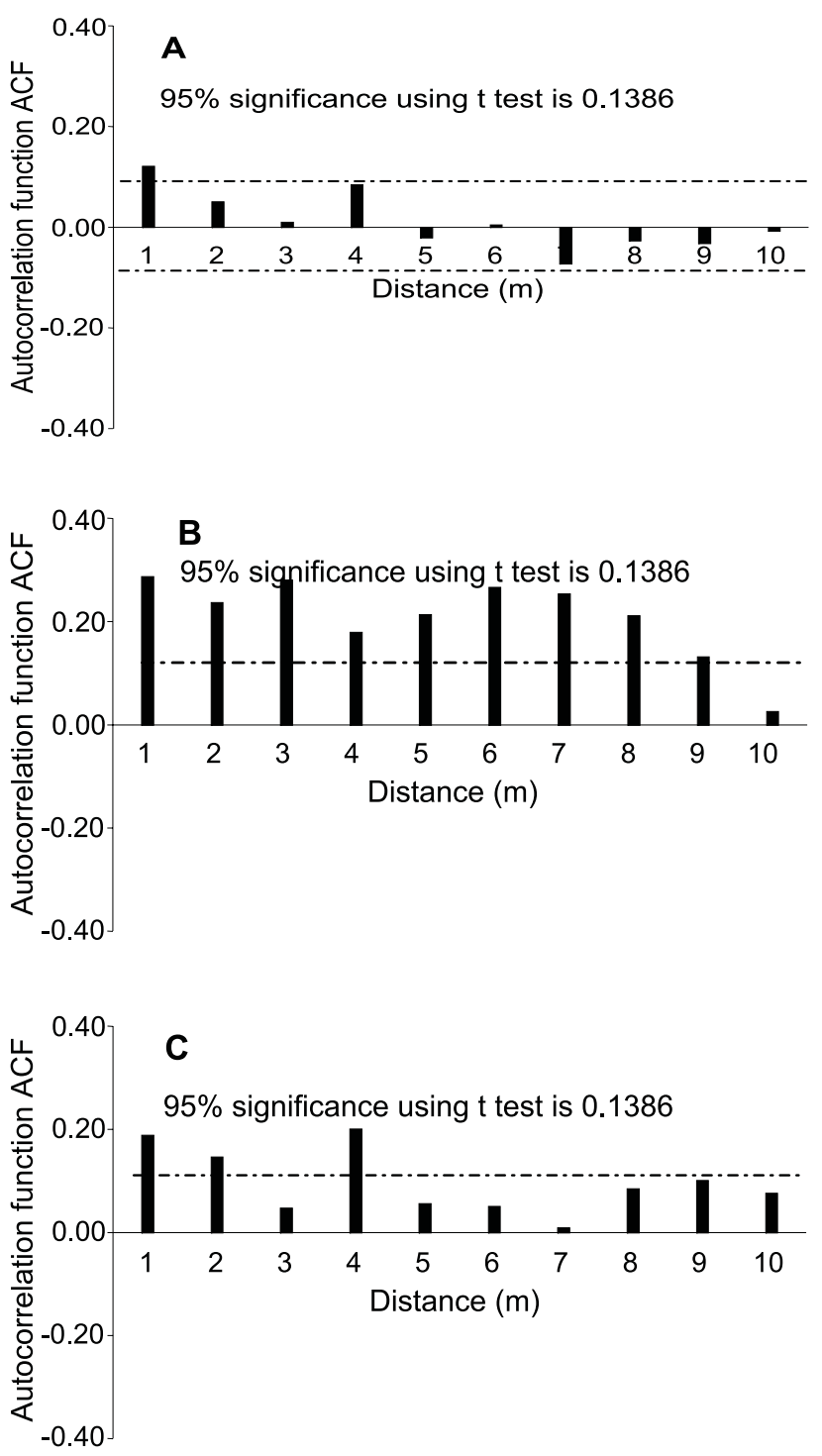

Figure 9 - Autocorrelation functions (ACF) for soil water content data sets for dates: (A) $\mathrm{MD}_{1}(07 / 04 / 2003)$; (B) $\mathrm{MD}_{2}$ (07/18/2003); and (C) $\mathrm{MD}_{3}(08 / 02 / 2003)$.

ferent dates. According to the CV classification proposed by Wilding \& Drees (1983), these $\rho_{\mathrm{s}}$ measurements can be classified as low variability $(\mathrm{CV}<15 \%)$. As an example, Grossman \& Reinsch (2002) reported $\rho_{\mathrm{s}}$ spatial variability of $10 \%$ and Warrick \& Nielsen (1980) found a $\rho_{s}$ of $7 \%$ for $\rho_{s}$ in three different experimental areas. Autocorrelograms for our data sets are shown in Figure 10.

Only for $\mathrm{MD}_{3}$ (Figure 10C) there was a spatial correlation for $2 \mathrm{~m}$ distance. Figures 4 and 10 reveal that adjacent $\rho_{\mathrm{s}}$ observations present a higher spatial dependence range in the dry period as compared to the wet period. This fact was also observed for the $\theta$ measurements. Crosscorrelation functions CCF between the differences $\Delta \theta$ and $\Delta \rho_{\mathrm{s}}$ and soil texture, are shown in Figure 11.
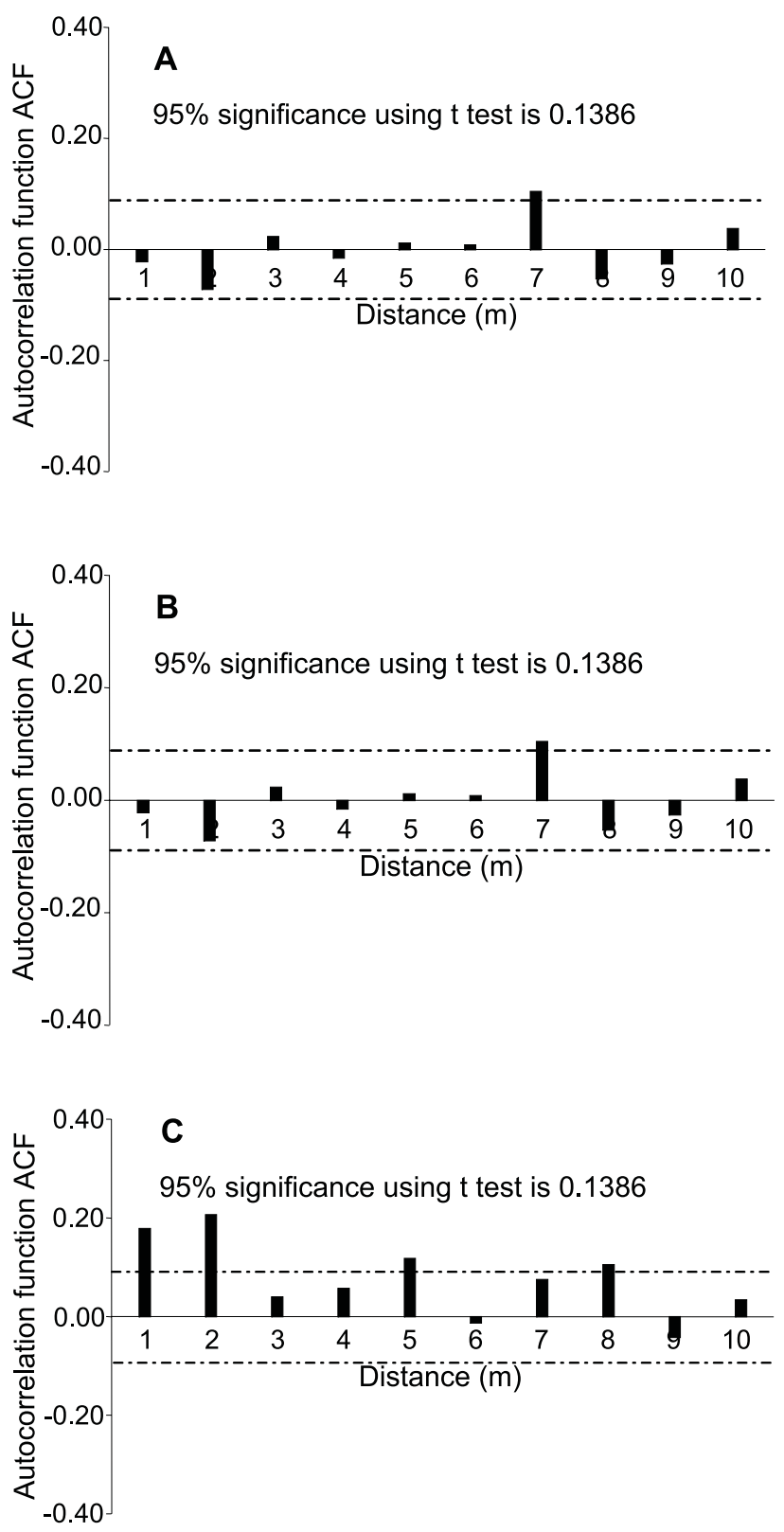

Figure 10 - Autocorrelation functions ACF for soil bulk density $\left(\rho_{s}\right)$ data sets for dates: (A) $\mathrm{MD}_{1}(07 / 04 / 2003)$; (B) $\mathrm{MD}_{2}(07 / 18 / 2003)$; and (C) $\mathrm{MD}_{3}(08 / 02 / 2003)$.

For the $\mathrm{MD}_{1}$ to $\mathrm{MD}_{2}$ period there is no significant spatial correlation between $\Delta \theta$ and: (i) $\Delta \rho_{\mathrm{s}}$ (Figure 11A); (ii) clay content (Figure 11B); (iii) sand content (Figure 11C); and (iv) silt content (Figure 11D); i.e., in this period, for lag $=0$, there is no correlation. Same results (not presented) were found for the $\mathrm{MD}_{2}$ to $\mathrm{MD}_{3}$ period.

From the soil water content autocorrelograms shown for wet (Figures 3A - C) and dry (Figures 9A - C) periods it is verified that the spatial correlation structure of $\theta$ measurements is not unique along the transect for the different dates, i.e., it is time-depen- 

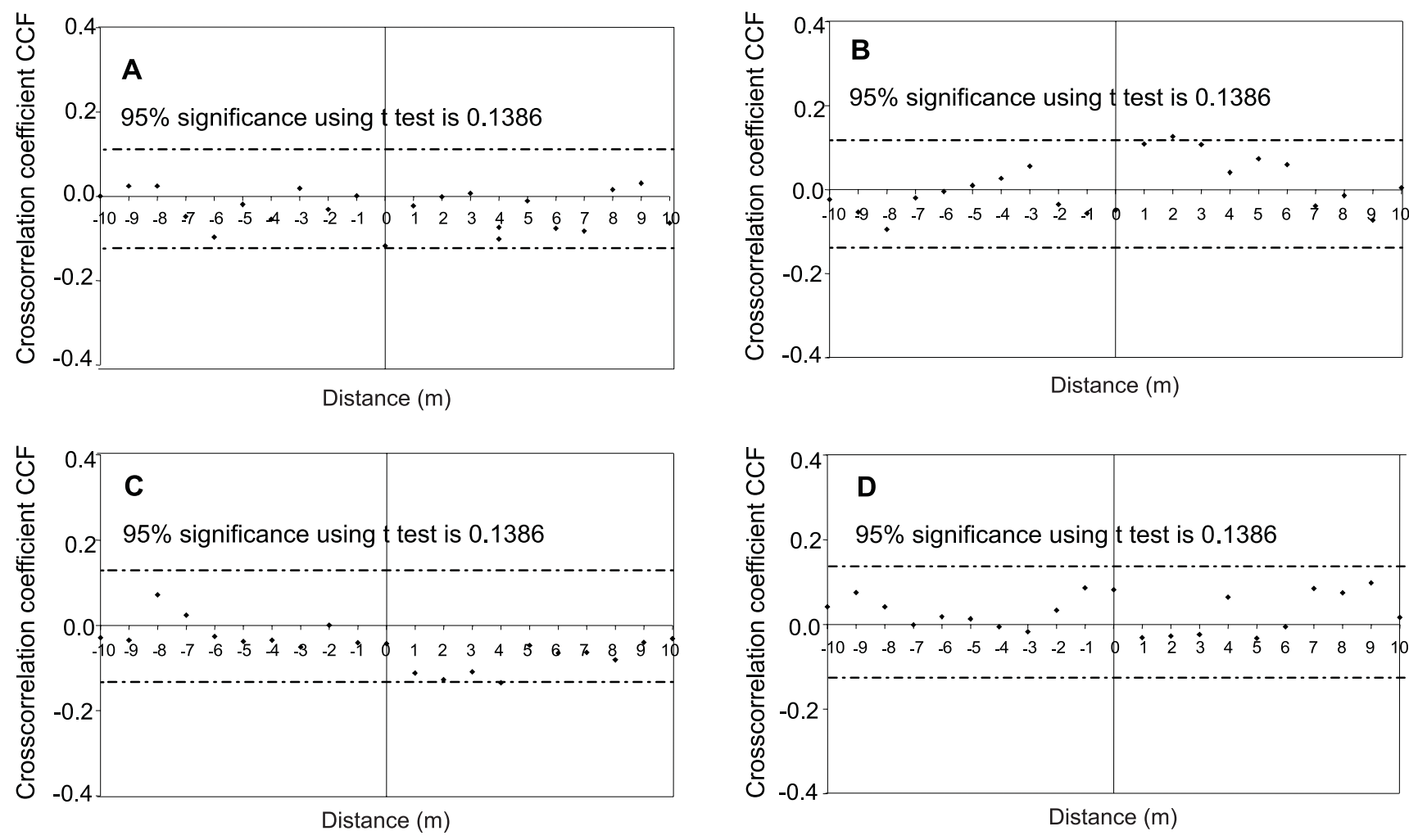

Figure 11 - Crosscorrelation functions (CCF) for soil water content variations $\Delta \theta\left(\mathrm{m}^{3} \mathrm{~m}^{-3}\right)\left(\mathrm{MD}_{1}(07 / 04)\right.$ to $\mathrm{MD}$ (07/18/2003)) for the dry period and: (A) soil bulk density variations $\Delta \rho_{\mathrm{s}}\left(\mathrm{Mg} \mathrm{m}^{-3}\right)$; (B) clay content; (C) sand content; and (D) silt content.

dent, not being unique within the field. The same behavior was observed for the crosscorrelograms shown in Figures 6A-B, 8A-C and 11A-D with a different spatial correlation structure among $\theta$ and $\rho_{\mathrm{s}}$ variations, and $\theta$ variations and soil texture. This can be attributed to the fact that $\theta$ is rarely in hydraulic equilibrium in the soil profile, constantly being under redistribution within the profile as a result of plant root extraction, evaporation and infiltration at the soil surface. Therefore, autocorrelograms and crosscorrelograms of soil water properties and attributes are not expected to be unique within a field (Nielsen \& Wendroth, 2003).

Comparisons made among the $\rho_{s}$ mean values for each date, to verify if there were significant temporal changes of the $\rho_{s}$ mean value along the studied period (April to August 2003) due to the natural mechanisms of consolidation of soil parent material in the $0-0.15 \mathrm{~m}$ soil layer of the experimental field, presented interesting results (Table 3). As mentioned before, the soil presents swelling and shrinking movements during the wetting and drying cycles along the different periods of the year. Based on the $\rho_{s}$ autocorrelograms in the wet (Figures 5A-C) and dry (Figures 10A-C) periods, and on the low CV values found for each soil bulk density data set (CVs ranged from $3.8 \%$ to $4.9 \%$ ), mean values of the $\rho_{s}$ data sets
Table 3 - Comparison among the soil bulk density $\rho_{\mathrm{s}}$ mean values $\left(\mathrm{Mg} \mathrm{m}^{-3}\right)$ for each date along all studied period using the Duncan statistical test at the 5\% probability level.

\begin{tabular}{lc}
\hline Date/measurement & Soil bulk density $\rho_{\mathrm{s}}$ mean \\
\hline & $\mathrm{Mg} \mathrm{m}^{-3 *}$ \\
$\mathrm{MW}_{1}(04 / 24 / 2003)$ & $1.532^{\mathrm{C}}$ \\
$\mathrm{MW}_{2}(05 / 07 / 2003)$ & $1.520^{\mathrm{C}}$ \\
$\mathrm{MW}_{3}(05 / 23 / 2003)$ & $1.560^{\mathrm{B}}$ \\
$\mathrm{MD}_{1}(07 / 04 / 2003)$ & $1.552^{\mathrm{B}}$ \\
$\mathrm{MD}_{2}(07 / 18 / 2003)$ & $1.558^{\mathrm{B}}$ \\
$\mathrm{MD}_{3}(08 / 02 / 2003)$ & $1.579^{\mathrm{A}}$ \\
\hline
\end{tabular}

measured at $\mathrm{MW}_{1}$ and $\mathrm{MW}_{2}$ dates can be obtained considering one hundred points as replicates; 200 points for $\mathrm{MW}_{3}, \mathrm{MD}_{1}$ and $\mathrm{MD}_{2}$; and sixty six points for $\mathrm{MD}_{3}$.

Soil bulk density temporal changes here presented (Table 3) indicate the $\rho_{\mathrm{s}}$ cannot be considered as a static soil property. It can also be observed that there is an increase of its mean value during the dry period as a consequence of shrinking soil movements. There are no significant differences among mean values of $\rho_{\mathrm{s}}$ for $\mathrm{MW}_{3}, \mathrm{MD}_{1}$ and $\mathrm{MD}_{2}$ and between $\rho_{\mathrm{s}}$ mean values for $\mathrm{MW}_{1}$ and $\mathrm{MW}_{2}$. Although $\mathrm{MW}_{3}$ was 
considered to belong to the wet period, its mean value along the spatial transect was not statistically different from the mean values for $\mathrm{MD}_{1}$ and $\mathrm{MD}_{2}$ which belong to the dry period.

\section{ACKNOWLEDGEMENTS}

To FAPESP, Capes and CNPq for financial support.

\section{REFERENCES}

AHUJA, L.R.; WENDROTH, O.; NIELSEN, D.R. Relationship between initial drainage of surface soil and average profile saturated conductivity. Soil Science Society of America Journal, v.57, p.1925, 1993.

BOONE, F.R.; VEEN, D.E. Mechanisms of crop responses to soil compaction. In: SOANE, B.D.; VAN OUWERKERK, C. (Ed.) Soil compaction in crop production. New York: Elsevier, 1994. p.237264.

CÁSSARO, F.A.M.; TOMINAGA, T.T.; BACCHI, O.O.S.; REICHARDT, K.; OLIVEIRA, J.C.M.; TIMM, L.C. Improved laboratory calibration of a single-probe surface gamma-neutron gauge. Australian Journal Soil Research, v.38, p.937-946, 2000.

CASSEL, D.K. Spatial and temporal variability of soil physical properties following tillage of Norfolk loamy sand. Soil Science Society of America Journal, v.47, p.196-201, 1983.

DOURADO-NETO, D.; TIMM, L.C.; OLIVEIRA, J.C.M.; REICHARDT, K.; BACCHI, O.O.S.; TOMINAGA, T.T.; CASSARO, F.A.M. State-space approach for the analysis of soil water content and temperature in a sugarcane crop. Scientia Agricola, v.56, p.1215-1221, 1999.

EMPRESA BRASILEIRA DE PESQUISA AGROPECUÁRIAEMBRAPA. Centro Nacional de pesquisa de Solo. Manual de métodos de análise de solos. 2.ed. Rio de Janeiro: EMBRAPA, CNPS, 1997. 212p.

GRAYSON, R.B.; WESTERN, A.W.; CHIEW, F.H.S. Preferred states in spatial soil moisture patterns: local and nonlocal controls. Water Resources Research, v.33, p.2897-2908, 1997.

GROSSMAN, R.B.; REINSCH, T.G. The solid phase: 2.1. Bulk density and linear extensibility. In: DANE, J.H.; TOPP, G.C. (Ed.) Methods of soil analysis. Part 4. Physical methods. Madison: SSSA, 2002. ch.2, p.201-228. (Book Series, 5).

KUTILEK, M.; NIELSEN, D.R. Soil hydrology. Cremlingen-Destedt: Catena Verlag, 1994. 370p.

LOGSDON, S.D.; CAMBARDELLA, C.A. Temporal changes in small depth incremental soil bulk density. Soil Science Society of America Journal, v.64, p.710-714, 2000.

LOGSDON, S.D.; KARLEN, D.L. Bulk density as a soil quality indicator during conversion to no-tillage. Soil \& Tillage Research, v.78, p.143149, 2004.

MARIN, F.R. Evapotranspiration and maximum transpiration in a high density coffee plantation. Piracicaba: USP/ESALQ, 2003. 118p. (Dissertação - Mestrado)

MARTÍNEZ, L.J.; ZINCK, J.A. Temporal variation of soil compaction and deterioration of soil quality in pasture areas of Colombian Amazonia. Soil \& Tillage Research, v.75, p.3-17, 2004.

MCGRAW, T. Soil test level variability in Southern Minnesota. Better Crops with Plant Foods, v.78, p.24-25, 1994.
MENDES, A.N.G. Cultivares com potencialidade para lavouras irrigadas. In: SANTOS, C.M.; MENDONÇA, F.C.; MELO, B.; TEODORO, R.E.F.; SANTOS, V.L.M. (Ed.) Irrigação da cafeicultura no cerrado. Uberlândia: Universidade Federal de Uberlândia, 2001. p.125-135.

MORKOC, F.; BIGGAR, J.W.; NIELSEN, D.R.; ROLSTON, D.E. Analysis of soil water content and temperature using State-space approach. Soil Science Society of America Journal, v.49, p.798803, 1985.

NIELSEN, D.R.; WENDROTH, O. Spatial and temporal statistics: sampling field soils and their vegetation. Reiskirchen: Catena Verlag, 2003. 398p.

REICHARDT, K.; TIMM, L.C. Solo, planta e atmosfera: conceitos, processos e aplicações. Barueri: Manole, 2004. 478p.

RENA, A.B.; MAESTRI, M. Ecofisiologia do cafeeiro. In: CASTRO, P.R.C.; FERREIRA, S.O.; YAMADA, T. (Ed.) Ecofisiologia da produção agrícola. Piracicaba: Potafos, 1987. p.119-145.

SAS INSTITUTE. System for information. Version 6.11. Cary: SAS Institute Inc., 1996.

STEPNIEWSKI, W.; GLINSKI, J.; BALL, B.C. Effects of compaction on soil aeration properties. In: SOANE, B.D.; VAN OUWERKERK, C. (Ed.) Soil compaction in crop production. New York: Elsevier, 1994. p.167-169.

TIMM, L.C.; REICHARDT, K.; OLIVEIRA, J.C.M.; CASSARO, F.A.M.; TOMINAGA, T.T.; BACCHI, O.O.S.; DOURADO-NETO, D. Sugarcane production evaluated by the state-space approach. Journal of Hydrology, v.272, p.226-237, 2003.

TIMM, L.C.; REICHARDT, K.; OLIVEIRA, J.C.M.; CASSARO, F.A.M.; TOMINAGA, T.T.; BACCHI, O.O.S.; DOURADO-NETO, D.; NIELSEN, D.R. State-space approach to evaluate the relation between soil physical and chemical properties. Brazilian Journal of Soil Science, v.28, p.49-58, 2004.

TOMINAGA, T.T.; CÁSSARO, F.A.M.; BACCHI, O.O.S.; REICHARDT, K.; OLIVEIRA, J.C.M.; TIMM, L.C. Variability of soil water content and bulk density in a sugarcane field. Australian Journal of Soil Research, v.40, p.605-614, 2002.

VIEIRA, S.R.; NIELSEN, D.R.; BIGGAR, J.W. Spatial variability of field-measured infiltration rate. Soil Science Society of America Journal, v.45, p.1040-1048, 1981.

WARRICK, A.W.; NIELSEN, D.R. Spatial variability of soil physical properties in the field. In: HILLEL, D. (Ed.) Applications of soil physics. New York: Academic Press, 1980. p.319-344.

WENDROTH, O.; REUTER, H.I.; KERSEBAUM, K.C. Predicting yield of barley across a landscape: a state-space modeling approach. Journal of Hydrology, v.272, p.250-263, 2003.

WENDROTH, O.; JÜRSCHIK, P.; KERSEBAUM, K.C.; REUTER, H.; VAN KESSEL, C.; NIELSEN, D.R. Identifying, understanding, and describing spatial processes in agricultural landscapes - four case studies. Soil \& Tillage Research, v.58, p.113-127, 2001.

WENDROTH, O.; POHL, W.; KOSZINSKI, S.; ROGASIK, H.; RITSEMA, C.J.; NIELSEN, D.R. Spatio-temporal patterns and covariance structures of soil water status in two Northeast-German field sites. Journal of Hydrology, v.215, p.38-58, 1999.

WILDING, L.P.; DREES, L.R. Spatial variability and pedology. In: WILDING, L.P.; SMECK, N.E.; HALL, G.F. (Ed.) Pedogenesis and soil taxonomy: concepts and interactions. New York: Elsevier, 1983. p.83-116.

Received February 03, 2005

Accepted December 19, 2005 